\title{
READERS
Insight
}

Journal of Management Info (JMI)

ISSN:2313-3376

www.readersinsight.net/jmi

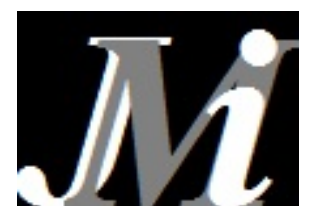

\section{Perceived Sources of Stress among faculty members of COMSATS institute of information technology, Pakistan}

\author{
Rosman Bin Md Yusoff ${ }^{1}$, Kamran Azam² \\ ${ }^{1}$ Fakulti Sains, Teknologi Dan Pembangunan Insan, Universiti Tun Hussein Onn Malaysia, Malaysia \\ ${ }^{2}$ Faculty of Management Science, Riphah International University, Pakistan \\ * Corresponding author:
}

\begin{abstract}
The present study aims at exploring the perceived sources of stress among the faculty members of COMSATS Institute of Information Technology, Pakistan by examining the stress coping methods used by faculty members for devising proposed stress management practices to faculty members. Two self administered questionnaires were distributed among 150 randomly selected teachers from five campuses of (CIIT), Pakistan. The $1^{\text {st }}$ questionnaire comprised 20-items regarding five teacher's stressors while the second questionnaire contained 10-itmes about the individual stress copying techniques. Scores for items on stressors \& stress copying techniques were computed by adding weights assigned and then an Exploratory Factor analysis was run for extracting stress contributing factors. The total teacher's stress score ranged from 25 to 100 in which female, $25-30$ years age group \& single teacher had high stress scores. Total 18 items were loaded high $(0.60+)$ on the five factors of stress after factor analysis. Majority of teachers (64\%) practiced behavioral self control, exercise and relaxation techniques for coping stress.This study doesn't investigate casual link between stress and stress contributing sources among teachers. The results of the study are useful both to academic world and to educational policy makers. This study is an addition to existing knowledge on university teachers' stress in Pakistan. The awareness about stress contributing factors is vital to the university teachers in Pakistan because the problem of teachers' stress if left unchecked can have devastating effects both on teachers as well on students
\end{abstract}

\section{ARTICLE INFORMATION}

$\begin{array}{ll}\text { Received: } & 25 \text { January } 2017 \\ \text { Revised: } & 25 \text { February } 2017\end{array}$

Accepted: 25 March 2017

DOI:

http://dx.doi.org//10.31580/jmi.v4i1.28

Keywords: Faculty's Stress, Educational Institutions, Pakistan, Case Study, Teacher Stress Questionnaire, Factor Analysis

\section{Introduction}

There are many professions in the world which involve helping others. Such like professions require intensive interactions with others in such a way that there is a need of persuasion for getting things done through others. People in these professions include teachers, doctors, nurses, and managers, e.t.c. These professions are very demanding; requires a never ending commitment and hard work, leading to a persistent exposure to some unwanted pressures, which vary from psychological to physical. These pressures sometimes become greater than available tolerance of the people working in such profession, thus leading to a state which can be termed as stress.

We are living in a knowledge era; the lives of people are mostly dependent on learning and disseminating of knowledge. The learning process in institutionalized form is known as education. Within educational system, the teacher is a vital person, which runs and maintains the educational system of any society at different levels, ranging from school to university. Among these all levels the university teaching is considered as more sophisticated; which involve not only teaching of higher level courses to senior students but also requires engagement in research related activities. Hence subjecting the university's teachers to more work load, where they have to fulfill complex demands of academia.

The existence of stress has been identified in almost all occupations, including teaching (Gmelch, 1993; Olivier and Venter, 2003). There was time when teaching in general (Fisher, 1994; Olsgaard John and Summers William, 1986) and specifically teaching in university was considered as low stress occupation (Thorsen E J, 1996; Winefield et al., 2003). The academicians working in universities were considered to have light workloads, flexible working hours, better salaries, and freedom pursuing their own research activities to contribute more to the overall body of knowledge. However with passage of time these comforts no longer exist due socio economic and political changes worldwide, which have affected even universities. Universities are facing problems like cuts on the budgets (Sherman Hugh, 2011; Winefield et al., 2003); teachers' work load has increased, jobs are no more secure, the technological complexity has created problems for teacher, and constant pressure comes from university administration on teachers with regard to daily activities, hence universities are going under process of transition (Fisher, 1994; Chang Ping and Tseng Mei, 2009). Therefore the university teaching has been recognized as stress full occupation. Research studies conducted on university teacher's stress like (Gillespie et al., 2001; Winefield et al., 2003; Jing Lizhen, 2008; Gunbayi Ilhan, 2009; Safaria and Othman, 2011) support this claim by explaining the various facet of university teachers' stress.

The problem of teachers' stress is more severe in country like Pakistan, where the university teachers have different problems. These problems are economical, social, institutional \& governmental in nature, which exert it pressure on teachers, and resultantly causing stress. Since the current study explores the perceived sources faculty's 
job stress in Pakistan, by taking CIIT as a special case therefore, it would be useful to review the common problems of university teachers in Pakistan so that the readers develop a general idea about the nature of faculty's job stress in higher education sector of Pakistan.

The economic situation of Pakistan is not currently good. High inflation rates and resources shortage have badly hampered lives of the common citizens of Pakistan. The salaries and other remunerations which the university teachers takes are largely spend on their living cost and very less amount is left for their personal development, especially for updating their educational qualifications $\&$ for conducting research related scholarly activities. This causes general job dissatisfaction and poor morale among them.

The social status of teacher is not as much higher like other administrative services of Pakistan. The Pakistani society is culturally status conscious. The status of a typical teacher has remained like an individual with good qualification but with no authority in society. A study conducted by Park Thomas (2006) revealed that there are certain deterrents because of which people don't like to join teaching jobs and if they remained in teaching profession then they remain unhappy. These deterrents included the ordinary persons' and students' less respect for teachers. Similarly Travers and Cooper (1996) found that teachers suffer stress due to lack of social recognition.

Apart from the economic and social problems, the university teachers in Pakistan mostly face problems either from the institutional or from government side. The institutional problems include work overload, time constraints, inadequate recognition, overcrowded class less career development opportunities, changing job roles, less or no chances for participation in administrative decisions, poor physical working conditions, poor interactions with colleagues and lack of fair performance evaluation system, e.t.c. On other side the governmental problems include, ever changing higher reforms and policies, lack of budget for higher education sector, quality control \& accreditation concerns, entry tests, less scholarships for university teachers' development, e.t.c. These are broad range of problems, which badly hamper the academic functioning of teachers.

After going through the problems of university teachers in Pakistan, let's come to the COMSATS Institute of Information Technology, Pakistan. The Commission on Science and Technology for Sustainable Development in the South is an inter-governmental organization. It has established CIIT as a degree awarding institute under the umbrella of Ministry of Science and Technology, Government of Pakistan; having campuses in seven cities of Pakistan, with its Headquarters in Islamabad, Pakistan. This institution has passed through different stages of development and presently its three campuses situated at Abbotabad, Lahore, and Islamabad are well established, and the rest of four campuses situated at Wah, Attock Sahiwal and Viharhi are under the process of development. CIIT is trying its best to meet the quality standards of HEC of Pakistan. According to CIIT ranking, It is standing at second position in terms of research citations, among universities in Pakistan \& has been ranked among the top four institutions of higher education, during 2005-07 by the HEC, with an overall seventh ranking in the Engineering discipline according to the HEC ranking issued in 2008 (CIIT Ranking in Pakistan, 2010).

\section{Statement of the research problem}

Teaching is a very noble profession. The success of any nation depends on how the young students are getting education. It is hard to think that a teacher under stress will produce good students. Perhaps, the lack of concern towards teacher problems is due the lack of understanding about the problems of a teacher. Therefore, keeping in view earlier discussed stress contributing problems faced by the university teachers of Pakistan, this study will attempt to explore the perceived sources of stress among the faculty members working in the five campuses of COMSATS Institute of Information Technology, Pakistan by examining the stress coping methods used by faculty members. The knowledge of various sources of job stress among the faculty member will lead to creation of awareness about the phenomenon of teacher's stress and will ultimately help in developing solutions for reduction of teacher's stress at institutional level.

\section{Research questions}

Following are the research questions of this study:

1. What is the general level of job stress among the faculty members of CIIT?

2. Are there any significant differences in the general job stress level in terms of respondent's gender, age, marital status, department and campus location?

3. What do the faculty members of CIIT consider to be the dominant sources of Job stress?

4. What do the faculty members of CIIT consider to be effective stress coping methods (as used by them) to reduce the overall prevalent job stress?

\section{Methodology}

\section{Design}

The present study is using a case study research design. According to Researcher Yin Robert K (2009), the case study is an empirical investigation of certain contemporary phenomenon by putting it in a real-life context, where the borders between phenomenon and context are not obvious; and in which multiple sources of proof are used. In fact a case study is undertaken in order in order to know the detail of phenomenon and this detail provide valuable insight for problem solving (Cooper Donald and Schindler Pamela, 2003).

\section{Population of study}

The respondents of the present study comprised of 150 randomly selected faculty members of Management Science, Computer Science, Bio- Science \& Engineering departments of the five campuses of COMSATS Institute of Information Technology, Pakistan.

\section{Instrument and data analysis}

Two self administered questionnaires were used for data collection. One was Teacher Stress Questionnaire (TSQ). This questionnaire comprised of 20-items regarding five teacher's stressors, i.e. students, parents, colleagues, institutional, \& governmental. These stressors were measured by a Likert scoring procedure, i.e. (1-Not all Stressful, 2-Mildly Stressful, 3-Moderately Stressful, 4-Highly stressful, 5- Extremely stressful). The items included in questionnaire were based on a consideration of studies of teachers stress by Cockburn (1996), Kyriacou (2001), Troman and Peter (2001). The second questionnaire contained 10-itmes about the individual stress coping techniques practiced by the faculty members of CIIT, Pakistan. Both descriptive techniques like mean, standard deviation and percentages as well as inferential statistics technique like Exploratory Factor analysis have been used for data analysis.

\section{Procedure}

The researcher collected the data electronically by online distribution of both questionnaires. The questionnaires along-with filling guidelines were e-mailed to the randomly selected 150 faculty members of five campuses. The data collection process took two and half months time, as some faculty members didn't give response to email, therefore, such like respondents were contacted through land line telephone calls and were requested to fill the questionnaire, already e-mailed to them. The data was extracted from the filled questionnaires and was then analyzed.

\section{Research model}

The conceptual model (Figure No: 1) for the faculty's job stress, is consisted of three parts. In the first part, on the right side, the five sources of teacher's stress, i.e. colleagues, parents, government, institution and student have been mentioned. These sources exist within or outside the educational institutions. In the middle of the 
model there is the second part, which is the stress being developed as a result of the prevalent teacher's stress sources. This stress causes poor performance and health related problems among the faculty members. The third and the last part of the model, on the left side, show the stress management techniques being used by the faculty members. The direction of the stress is denoted by the arrows, which are heading from right side to left side. This model helps in conceptualizing the faculty's stress in such way that faculty's stress is developed as result of the stressors which are present within the environment, which lead to poor performance. The teachers ultimately use the stress management techniques for minimizing the bad effects of stress. The problem of faculty's stress is often resolved after the application of stress management techniques, but if the sources of stress persist to exist then stress management techniques doesn't work and faculty member continually suffer from the bad effects of stress.

\section{Literature review}

Job stress has been conceptualized as a force, which is beyond the person's normal physical or psychological controls, that creates an imbalance, and the person is forced to deviate from normal functioning. It is a human reaction to the negative or unwanted situational factors (Cooper, Dewe , and O'Driscoll, 2001; Beehr Terry, 2002; Nakao Mutsuhiro, 2010). The teacher stress is a state where the teachers come under an immense pressure of the existing environmental factors which lead to creation of imbalance in the normal routine functioning of the teachers ( Kyriacou, 2001; Van Dick and Wagner, 2001 Al Fudail and Mellar, 2008)

In fact the stressfulness of teaching as an occupation has been widely recognized. Research studies conducted on university teacher's stress like (Winefield et al., 2003; Jing Lizhen, 2008; Gunbayi Ilhan, 2009; Safaria and Othman, 2011) explains the various facet of teachers' stress. This indicates that teachers' stress is becoming endemic all over the world.

The perceived stress among the teachers can have devastating effects both on teachers as well the institutions, where teachers work. Individually the teachers' work efficiency can suffer, motivation \& job satisfaction can be lowered, and they can suffer from serious health problems, where as stress stricken educational institutions are non-productive and stagnant. It has been argued by researchers that the effects of stress in teaching field largely fell on individual teachers, which results in both physical as well as psychological problems. Dua Jagdish, (1994); Barkhuizen and Rothmann,( 2008) and Fako Thabo, (2010) found that teachers' stress was associated with poor emotional and physical health, in such way that the teachers who suffered from stress developed anxiety, muscular tension, head ache, feeling of loneliness, irritability, hopelessness, emotional hardiness, fatigue and Insomnia and were absent from work with frequent visits to doctors. So far as the effects of stress on educational institutions are concerned then Dua Jagdish, (1994); Winefield et al. (2003) and Mostert et al. (2008) found there is more absenteeism, job dissatisfaction, low quality, poor morale of teachers, and over all reduced institutional productivity in educational institutions hit by occupational stress. The overwhelming effects of stress even negatively affect the social lives of teachers. Stressed teachers have often poor family life, as they cannot fully play their family roles. Cinamon and Rich (2005) conducted a study on work and family conflict and the effects of stress on the personal lives of 187 Israeli women teachers, and found that the stress negatively affected the family lives of selected women teachers. Thus the effects of stress vary from individual to institution and social lives of teachers.

The sources of teacher's stress vary from situation to situation and from country to country. The stress sources in western world may be different from that of eastern. However, there is a general agreement on certain sources of teacher's stress, which prevails universally. Among the sources of teachers' stress, the stressors which are present within institution are considered to the dominant. Sharpley et al. (1996); Kyriacou (2001); Forlin (2001); stated that rigid institutional polices, less career progression chances, work overload, less benefits and poor working condition, leads to the development of stress among the teachers. Furthermore, the presence of too many students in a class, the misbehavior from students' side, students who have emotional or behavioral problems, who don't exhibit expected results, and students' conflicts, becomes sources of stress for the teachers (He Xing Xiao, et al. 2000; Geving Allison, 2007). Like students, the colleagues can also be source of stress, as pointed out by (Caroline Biron et al., 2008; Archibong et al., 2010; Eres and Atanasoska, 2011). They found that the poor working relationship between colleagues, colleagues' politics, low trust among colleagues and competition within colleagues lead to development of teacher's stress. Apart from the institutional stressors, there are certain stressors which lie outside the institution. These stressors include parents, and governmental policies. Prakke Bette, et al., (2007), Eres and Atanasoska,( 2011) have stated that less communication between parents and teachers, hostile or non cooperative parents, and ever demanding parents become a source of stress for teachers. So far as the governmental policies are concerned then Travers, et al., (1996), Fisher, 1994 and Winefield et al. (2003) have pointed out that the government policies regarding downsizing, redeployment, early retirement, and rapid curriculum change creates stress among the teachers, especially when the teachers fails to comply the governmental regulations. The teacher's stress management is a broad line process in which multi dimensions of stress are needed to be addressed, because if any of aspect left unaddressed, then stress management would not be properly ensured and the victims of stress will continually suffer from the negative effects of stress. The teacher's stress management program can be broadly divided in to individual, group, and organizational levels. On the individual level the teachers should aim at clarifying their work roles and tasks, so that they don't suffer from role or task conflicts. The teachers need to set proper time table for their routine activities, in order to avoid work over load and working at odd timings (Jesus and Conboy, 2001). The teachers should be given stress coping training in which the main focus should be on control of emotions. Such training should focus on physical relaxation and on cognitive strategies, including rehearsal in imagination for preparing in advance for the future stress situations (Stein and Cutler, 2002; Linden Wolfgang, 2005; Gold et al., 2010). At the group and organizational levels, the workers should be given support, either by deploying a full time counselor, who could provide the needed counseling services or the immediate supervisors should provide support to the employees in overcoming the job stress. In this regard the employees' assistance programs are very much effective (Russell et al., 1987; Hodge et al., 1994; (Stein and Cutler, 2002). The teacher's stress management either at individual, group or organizational level, should ensure that it buffers the negative effects of various sources of stress, so that maximum positive results of stress management program can be achieved.

After having a review of the origin, sources \& effects of teachers stress, it is clear that teachers' stress is an emerging problem in the world of academia. It is adversely affecting the teachers' population throughout the whole world. It is of unique importance, firstly to teachers, and then to the pupils and parents, because the pupils and parents may indirectly get affected by the negative consequences of teacher's stress. The best possible solution to teacher's stress is the identification, recognition and diagnosis, of the potential sources of stress in advance, in such way that appropriate stress management measures are taken before it victimizes teachers and jeopardizing their personal as well as professional lives.

\section{Data presentation}

The findings of the study are presented in four tables. The table: 1 is representing the demographic characteristics \& Average Stress Scores of the Respondents. The faculty members who have responded to the questionnaire had a mean age of 30 years. Gender wise there are more males as compared to female faculty members in different departments. Marital status wise there are more non-married faculty 
member as compared to married one. The department of Management Sciences has more number of faculty members as compared to other departments.

Table 1: Demographic Characteristics and Average Stress Scores of the Respondents (N: 150)

\begin{tabular}{llll}
\hline Demo. & Characteristics & Number \& \% & Avg. TSS \\
\hline \multirow{2}{*}{ Gender } & Males & $106(70.67 \%)$ & 48.00 \\
& Females & $44(29.33 \%)$ & 63.00 \\
\hline \multirow{4}{*}{ Age } & 20-25 years & $12(08.00 \%)$ & 35.00 \\
& 25-30 years & $81(54.00 \%)$ & 67.00 \\
& 30-35 years & $38(25.33 \%)$ & 53.00 \\
& 35-40 years & $19(12.67 \%)$ & 45.00 \\
\hline Sarital & Married & $63(42.00 \%)$ & 42.00 \\
\hline \multirow{5}{*}{ Department } & Single & $87(58.00 \%)$ & 55.00 \\
& Management Science & $65(43.33 \%)$ & 64.00 \\
& Computer Science & $28(18.66 \%)$ & 55.00 \\
& Engineering & $35(23.34 \%)$ & 51.00 \\
\multirow{5}{*}{ Campus } & Bio- Sciences & $22(14.67 \%)$ & 49.00 \\
& Abbotabad & $43(28.66 \%)$ & 66.00 \\
& Attock & $12(08.00 \%)$ & 47.00 \\
& Wah & $19(12.67 \%)$ & 54.00 \\
& Islamabad & $28(18.67 \%)$ & 62.00 \\
& Lahore & $48(32.00 \%)$ & 68.00 \\
\hline
\end{tabular}

Table 2: Factor Analysis of the Perceived Sources of faculty's job stress

\begin{tabular}{|c|c|c|c|c|c|c|}
\hline & \multirow[b]{2}{*}{ Stressors } & \multicolumn{5}{|c|}{ Factors } \\
\hline & & & 2 & 3 & 4 & 5 \\
\hline 1 & Students' misbehavior at lecturer or outside- lecture. & .091 & .033 & -.077 & .054 & .90 \\
\hline 2 & Students' who lack motivation \& Pupils' poor attitudes toward classroom tasks. & .022 & .355 & .301 & .302 & .86 \\
\hline 3 & Too many students in one class. & .049 & .194 & .048 & .206 & .93 \\
\hline 4 & $\begin{array}{l}\text { Special pupils in the class (e.g. with autism, attention - deficit and hyperactivity disorder low } \\
\text { ability or low emotional intelligence). }\end{array}$ & .059 & .031 & -.068 & .088 & .183 \\
\hline 5 & Lack of Communications to and from parents & .067 & .91 & -.025 & .026 & .077 \\
\hline 6 & $\begin{array}{l}\text { Parents are advocating for their children in wrong matters \& make undue demands from } \\
\text { teachers. }\end{array}$ & -.035 & .86 & -.014 & -.096 & .110 \\
\hline 7 & Meetings with parents often lead to a conflict, (felt more by parents than teachers). & .067 & .89 & -.025 & .026 & .077 \\
\hline 8 & $\begin{array}{l}\text { Parents fail or don't acknowledge the teacher's actions } \\
\text { benefits. }\end{array}$ & .078 & .81 & -.029 & .139 & .240 \\
\hline 9 & There is always work load and Poor working conditions. & .097 & .040 & -.021 & .87 & .140 \\
\hline 10 & Not enough teaching resources for the faulty members. & -.019 & .018 & -.146 & .68 & .064 \\
\hline 11 & Immediate boss's style is inappropriate and irritating. & .085 & .022 & .058 & .94 & .077 \\
\hline 12 & Fewer salaries or other benefits in comparison to other educational institutions. & .085 & .022 & .058 & .91 & .077 \\
\hline 13 & Competition between colleagues subordinates and boss. & .84 & -.077 & .087 & .077 & .053 \\
\hline 14 & Lack of privacy and being observed by colleagues in confidential personal matters. & .79 & .061 & .083 & .068 & -.043 \\
\hline 15 & Non trusty colleagues and back biting by colleagues. & .93 & -.025 & .067 & .043 & .021 \\
\hline 16 & Favoritism done by colleagues on basis of race, family- relations and other basis. & .80 & .077 & .087 & .077 & .053 \\
\hline 17 & Ever changing educational polices of the government & .103 & .030 & .68 & .062 & -.226 \\
\hline 18 & Lack of research grants and special incentives for the teachers. & .168 & .020 & .88 & .064 & .016 \\
\hline 19 & Lack of support from government and centralization of powers in decision making. & .020 & .017 & .95 & -.003 & .004 \\
\hline 20 & $\begin{array}{l}\text { banning of corporal punishment, redeployment of teachers, voluntary severance packages, } \\
\text { early retirement and retrenchment. }\end{array}$ & -.023 & .005 & -.877 & .015 & .150 \\
\hline
\end{tabular}

The first factor "colleagues" which accounted for about $19.125 \%$ of variance consisted of 4-items of Teacher Stress Questionnaire (TSQ). This means that among the other sources of faculty's job stress, "colleagues" is contributing more stress towards the total stress perceived by faculty members.

\begin{tabular}{llll}
\multicolumn{4}{l}{ Table 3: Factors extracted with resultant variances } \\
\hline Factors & Description & \% of Variance & Cumulative \% \\
\hline 1 & Colleagues & 19.125 & 19.125 \\
2 & Parents & 17.852 & 36.977 \\
3 & Government & 16.122 & 53.099 \\
4 & Institution & 15.133 & 68.232 \\
5 & Students & 11.973 & 80.205 \\
\hline
\end{tabular}

The second factor "parents" also consisted of 4-items of (TSQ) and has accounted for $17.852 \%$ of variance, which is the second significant contributing factor. Factor three "government" consisted of 3-items of (TSQ) and accounted $16.122 \%$ of variance, which is a closer to the fourth factor "institution", consisted of 4-itmes of (TSQ)
TSS: Teacher's Stress Score

Campus wise there are more faculty members in the campuses located in the cities of Lahore and Abbotabad and compared to the campuses located in the Wah, Islamabad and Attock. The Average Teachers' Stress Scores shows that the female faculty members, faculty members in age group of 25-30 years, unmarried one, and faculty member from Management Science Department have experienced more stress as their Average Teachers' Stress Scores are more than rest of faculty members.

The results of principal components, varimax rotation factor analysis, as shown in Table: 2, it is showing that out of the total 20 items, about 18 items have loaded high $(.60+)$ on the five factors produced by the factor analysis.

These five factors, i.e. (colleagues $19.125 \%$, parents $17.852 \%$, government $16.122 \%$, institution $15.133 \%$, and students $11.973 \%$ ) accounted for total $80.205 \%$ of cumulative variance after rotation. For detail see tables 2 and 3 . Analysts commonly use loading values between (.30) and (.60) for the factor coefficients interpretation (Andrew Comrey, 1978; Pohlmann, 2004). with $15.122 \%$ of variance. However the fifth factor "students", consisted of 3-items, resulted $11.973 \%$ of variance which is relatively less than the percentages of first three factors. This means that students are contributing less towards the total stress perceived by faculty members.

Table 4: Individual Stress Management Techniques (N: 150)

\begin{tabular}{lll}
\hline Techniques & Number & Percentage \\
\hline Exercise \& Relaxation & 38 & 25.33 \\
Behavioral Self Control & 48 & 33.37 \\
Cognitive Therapy & 15 & 10.00 \\
Networking \& Social Support & 35 & 23.00 \\
Adopting institutional practices & 14 & 09.33 \\
Total & 150 & 100 \\
\hline
\end{tabular}

Table 4 shows that among the 150 randomly selected faculty members, majority of them (3.37\%) have used behavioral self control techniques for management of job related stress, which includes practicing humor at workplace to cope tense situations, learning to control emotions during or after stressful situations, avoiding 
unwanted confrontations during work place or after work, forgetting all stressful events that have happened in campus, e.t.c. On other side $(25.33 \%)$ have used exercise and relaxation techniques, which includes doing regular physical exercise \& application of relaxation techniques and practice of religion and spirituality. The remaining $(23.00 \%)$ and $(10.00 \%)$ either practiced networking, and social support including doing discussion with friends, family members or spouse about work place problems or cognitive therapy including visiting any psychiatrist or psychologist for any possible treatment or counseling as techniques for management of job related stress.

\section{Discussion on findings}

Faculty's Job Stress is well recognized problem and studies shows that a large number of faculty members experiences job related stress, during their routine work at campus. The findings of the present study also show that faculty members of CIIT perceived their jobs to be stressful one. The finding of this study shows that the female teachers experienced more stress with an average TSS of 63.00 as compared to their male counter parts, with an average TSS of 48.00. Previous studies like Barkhuizen and Rothmann (2008) and Archibong et al., (2010) had same like findings of high stress among female teachers. This is primarily because the female teacher faces more professional and social problems as compared to male teachers. Age wise; the teachers within the age category of 25-35 years experienced more stress with average TSS of 60.00. Tytherleigh and Cooper (2007) also found that university teachers with in age of 25 or above experience more stress and physical health problems. Here as work as moderator, young teachers are under stress due to more work load and responsibilities in campus. The unmarried teachers with average TSS of 55.00 have perceived more stress as compared to married one. According to Cutrona Carolyn (1996) during the times of severe stress, support from spouse can prevent emotional withdrawal as marriage is one form of social support and thus prevents from bad effects of stress. Among the campuses; the teachers from Abbotabad and Lahore campuses have perceived more stress with average TSS of 67.00, because Lahore and Abbotabad campuses are relatively big campuses, having more problems, so the chances of getting exposed to job stress are more as compared to small campuses.

It has further been found that out of five total stressors, the three most important sources of stress for faculty members are colleagues, parents and government. The first source, "colleagues" contribute to development of work stress in such a way that there is competition between colleagues, subordinates \& boss, the faculty members have lack of privacy and are being observed by colleagues in confidential personal matters. There are non trusty colleagues and back biting is done by the colleagues and favoritism done by colleagues on basis of race, family- relations. Colleagues as source of teacher's stress has also been identified in studies conducted in past, e.g. (Caroline Biron et al., 2008; Archibong et al., 2010; Eres and Atanasoska, 2011). "Parents" is the second dominant source of stress for the faulty members. Prakke Bette, et al., (2007) and Eres and Atanasoska, ( 2011) have stated that less communication between parents and teachers, hostile or non cooperative parents, and ever demanding parents become a source of stress for teachers. The third one stress source is "government", Travers , et al., (1996), Fisher, 1994 and Winefield et al. (2003) have pointed out that the government policies regarding downsizing, redeployment, early retirement, and rapid curriculum change creates stress among the teachers, especially when the teachers fails to comply the governmental regulations.

Finally, looking at the individual stress copying techniques practiced by the faculty members then it has been revealed that faculty members have practiced the behavioral self control techniques ( like humor at workplace to cope tense situations, learning to control emotions during or after stressful situations, avoiding unwanted confrontations during work place or after work, forgetting all stressful events that have happened in campus) and exercise related relaxation techniques (like doing regular physical exercise \& application of relaxation techniques and practice of religion and spirituality) as compared to techniques like cognitive therapy or social support. Iwanicki Edward, 1983; Roger and Hudson, 1995 , Jesus and Conboy, 2001 found that physical exercise and self-regulation, behavioral self control techniques have been more effective in management of stress as compare to other techniques.

\section{Proposed stress management practices for faculty members}

The proposed Stress management practices for the faculty members of CIIT, Pakistan have been divided in to three categories, i.e. individual, group and institutional level. Individual level stress management practices involve:

1. The faculty member should adopt habit of doing regular exercise; this will help them to control the physical symptoms of stress such as muscular tension \& gastric problems, further more it will also help in reducing psychological tension, because physical exercise refreshes mind \& body as whole.

2. The faculty members should try to adjust their Circadian Rhythm and manage time by properly scheduling their routine activities and avoiding doing things at odd timings.

3. The behavioral self control practices like controlling of emotions at time of stress, thinking positively, avoiding of being perfectionist and not expecting too much from others can help in relieving the negative effects of stress.

4. Individual involvement in spiritual activities and religion can be supportive in fighting negative feelings due to stress.

5. Getting a hobby and spending time in re-creational activities can help in preventing negative effects of stress.

6. Never use any medications without prescription of registered medical practitioner.

Group level stress management practices involve:

1. The faculty members should share their ideas with each other, work in a group by dividing the responsibilities and support each other in routine activities.

2. Consulting and taking guidance from the experienced senior colleagues in difficult times can help in solving problems.

3. The faculty members should try to make a balance between the work place relations and personal family relations.

4. Encourage praising \& rewarding others for their good work.

Institutional level stress management practices involve:

1. The university administration should allocate tasks according to the aptitude and skills of the faculty members.

2. All the faculty members should be allocated work load on equal basis, in such way that no discrimination should be done on basis of gender, race or position.

3. The university should frequently arrange recreational events for engaging faculty and students in extracurricular activities.

4. There should be equal chances for promotion and career development.

5. Pay and salaries should be fixed according to the prevalent market rates.

6. The faculty members should not be forced to work in odd times.

7. A proper system should be arranged for leave and vacations.

8. A climate of openness and honesty should be established by making it safe for faculty members to express their views.

9. The university administration should give services like transportation, accommodation, sports club, child care center, evening time library, e.tc. so that faculty members feel that university cares about their well being.

10. The faculty members should be given regular trainings in their areas of expertise, which can enhance knowledge, skills and adaptive capabilities.

\section{Conclusion}

The paper concludes that teaching profession is stressful, and teachers all around the globe are facing the problem of job stress during their routine professional life. Faculty members at CIIT are not an exception, It is therefore, required that the problem of teacher's 
stress should not only be understood in-depth but also managed on time before it sets forth its devastating effects on teachers. The findings revealed that the marginalized faculty members like female, unmarried or relatively juniors, face more stress as compared to others. Colleagues, parents and government being the top stressors can play pivotal role in coping with the stress management and minimization.

This paper recommends a conducive work environment by ensuring more collaboration among colleagues. The parents are recommended to be dealt in a channelized way to focus more on the students' weaknesses rather pressurizing the faculty for better results. The government is pledged to bring stability in the policies and avoid rapid experimentations based on exporting ideas blindly from the west. The faculty members need to be made more aware of Individual stress management techniques.

The paper also recommends more research on the stress prevalence in other public sector universities, individual stressors, stress management mechanism and development of a stress free work place at universities to ensure better development of the future generations.

\section{References}

Andrew Comrey L. (1978), "Common methodological problems in factor analytic studies", Journal of consulting and clinical psychology. Vol. 46 No.4, pp.648-659.

Archibong, Aniedi Ijeoma , Bassey, Offiong Akpo, Effiom and Otu David. (2010), "Occupational Stress Sources among University Academic Staff", European Journal of Educational Studies, Vol. 2 No. 3, pp. 217-225.

Barkhuizen N and Rothmann S. ( 2008), "Occupational stress of academic staff in South African higher education institutions", South African Journal of Psychology, Vol.38 No.2, p. 327.

Beehr Terry. (2002), "An organizational psychology meta-model for occupational stress", in Cooper Cary By L (Ed), Theories of organizational stress, Oxford University Press, UK, pp. 6-27.

Caroline Biron, Jean-Pierre Brun and Hans Ivers. (2008), "Extent and sources of occupational stress in university staff", Work: A Journal of Prevention, Assessment and Rehabilitation, Vol. 30, No.4, pp. 511-522.

Chang Ping Cheng and Tseng Mei Ya. (2009), "An Exploration of Job Stress among academic heads in Taiwanese Universities", Social Behavior and Personality, Vol. 37 No. 5, pp. 583-590.

CIIT Ranking. (2010), "COMSATS Institute of Information Technology Ranking in Pakistan", available at: http://www.ciitisb.edu.pk/About\%20CIIT/Ranking.aspx (accessed 12 June 2011).

Cinamon Gali Rachel and Rich Yisrael. (2005), "Work-family conflict among female teachers. Teaching and Teacher Education”, Vol. 21 No.4, pp. 365-378.

Cockburn AD. (1996), "Primary teachers' knowledge and acquisition of stress relieving strategies", British Journal of Educational Psychology, Vol. 66 No.3, pp. 399-410.

Cooper Cary L., Dewe Philip and Driscoll Michael P. (2001), Organizational Stress: A Review and Critique of Theory, Research, and Applications, Sage Publications USA.

Cooper Donald R and Schindler Pamela S. (2003), Design Strategies in Business research methods", Tata MC, Graw Hills Publishing Company, New Delhi, p. 149.

Cutrona Carolyn. (1996), Social support in couples: Marriage as a resource in times of stress, Sage Publications Inc, USA, pp. 59-60.

Dua Jagdish. (1994), "Job Stressors and Their Effects on Physical Health, Emotional Health and Job Satisfaction in a University", Journal of Educational Administration, Vol. 32 No.1, pp. 59-78.

Eres Figen and Atanasoska Tatjana.(2011), "Occupational Stress of Teachers: A Comparative Study Between Turkey and Macedonia", International Journal of Humanities and Social Science, Vol.1 No. 7, pp. 59-65.

Fako Thabo T. (2010), "Occupational Stress among University Employees in Botswana", European Journal of Social Sciences, Vol.15 No. 3, p. 319

Fisher, S. (1994), Stress in Academic Life: The Mental Assembly Line, Buckingham: Open University Press, p. 61.

Forlin C. (2001), "Inclusion: identifying potential stressors for regular class teachers", Educational Research, Vol. 43 No. 3, pp. 235-245.

Geving Allison M. (2007), "Identifying the types of student and teacher behaviors associated with teacher stress", Teaching and Teacher Education, Vol. 23 No. 5, pp.624-640.

Gillespie, M Walsh, Winefield and Dua Stough.(2001), "Occupational stress in universities: staff perceptions of the causes, consequences and moderators of stress", Work \& Stress, Vol. 15 No.1, pp. $53-72$.
Gmelch, W. H. (1993), Coping with faculty stress, New York: Sage Publications, USA.

Gold Eluned, Smith Alistair, HoppeIeuan, Herne David, Tansey Glenis and Hulland Christine. (2010), "Mindfulness-Based Stress Reduction for Primary School Teachers", Journal of Child and Family Studies, Vol.19 No. 2, pp. 184-189.

Gunbayi Ilhan. (2009), “Academic staff's perceptions on stressors originating from interpersonal relations at work setting: a case study", Procedia Social and Behavioral Sciences, Vol.1 No. 1, pp. 50-60.

He Xing Xiao, Li Yu Zhu, Shi Jian, Mao Rong, Mu Hua Rong and Zhou An Yi. (2000), "A Comparative Study of Stress among University Faculty in China and Japan", Higher Education, Vol.39 No.3, pp. 253-278.

Hodge GM, Jupp JJ and Taylor AJ. (1994), "Work, stress, distress and burnout in music and mathematics teachers", British Journal of Educational Psychology, Vol. 64 No.1, pp. 65-76.

Iwanicki Edward. (1983), "Toward Understanding and Alleviating Teacher Burnout", Theory into Practice, Vol. 22 No.1, pp. 27-32.

Jesus de Neves Saul and Conboy Joseph. (2001), "A stress management course to prevent teacher distress", The International Journal of Educational Management, Vol.15 No.3, pp. 131-134.

Jesus de Neves Saul and Conboy Joseph. (2001), “A stress management course to prevent teacher distress", The International Journal of Educational Management, Vol. 15 No. 3, pp.131-137.

Jing Lizhen. (2008), "Faculty's job stress and performance in the undergraduate education assessment in China: A mixed-methods study", Educational Research and Review, Vol. 3 No. 9, pp. 294-300.

Jing Lizhen. (2008), "Faculty's job stress and performance in the undergraduate education assessment in China: A mixed-methods study", Educational Research and Review, Vol. 3 No. 9, pp.294-300.

Kyriacou C. (2001), "Teacher stress: directions for future research", Educational Review, Vol. 53 No.1, pp. 27-35.

Linden Wolfgang. (2005), Stress management: From basic science to better practice, Sage Publication Inc, USA, pp: 73-74, 91-118.

Mostert F.F., Rothmann S., Mostert K and Nell K. (2008), "Outcomes of occupational stress in a higher education institution", Southern African Business Review Volume, Vol. 12 No.3, pp. 102-127.

Nakao Mutsuhiro. (2010), "Work-related stress and psychosomatic medicine", BioPsychoSocial Medicine, Vol. 4 No.4, pp. 2-5.

Olivier, M. A and Venter D. (2003), "The extent and causes of stress in Teachers in the George region", South African Journal of Education, Vol. 23 No. 3, pp.186-192.

Olsgaard John N. and Summers William F. (1986), "Sources of Job-Related Tension among Administrators and Faculty", Journal of Education for Library and Information Science, Vol. 27 No. 2, pp. 90-99.

Park Thomas .(2006), "Teaching as a career choice: attractors and deterrents identified by Grade 11 learners", South African Journal of Education, Vol 26 No. 1, pp. 143-156

Pohlmann John T. (2004), "Use and Interpretation of Factor Analysis", The Journal of Educational Research, Vol. 98 No. 1, pp. 14-22.

Prakke Bette, Peet Van Arie and Wolf Der Van Kees. (2007), "Challenging parents, teacher occupational stress and health in Dutch primary schools", International Journal about Parents in Education, Vol. 1 No.0, pp. 36-44.

Roger Derek and Hudson Chris. (1995), "The Role of Emotion Control and Emotional Rumination in Stress Management Training”, International Journal of Stress Management, Vol. 2 No. 3, pp. 119-130.

Russell D.W, Altmaier E and Van Velzen D. (1987), "Job-related stress, social support, and burnout among classroom teachers", Journal of Applied Psychology, Vol. 72 No.2, pp.269-74.

Safaria Triantoro and Othman bin Ahmad. (2011), "The Role of Leadership Practices on Job Stress among Malay Academic Staff: A Structural Equation Modeling Analysis", International Education Studies, Vol. 4 No. 1, pp. 90-100.

Sharpley F., Reynolds, Acosta and Dua, J. K. (1996), “The presence, nature and effects of job stress on physical and psychological health at a large Australian university", Journal of Educational Administration, Vol. 34 No.4, pp. 73-86.

Sherman Hugh D. (2011), "What is the future of the public university?", American Journal of Business, Vol. 26 No. 1

Stein F and Cutler S (2002), Psychosocial Occupational Therapy: A Holistic Approach, San Diego: Singular Publishing.

Thorsen Elizabeth J. (1996), "Stress in Academe: What Bothers Professors?" Higher Education, Vol.31, pp. 471-489.

Travers, C. J and Cooper, C. L. (1996), Teachers under pressure: Stress in the teaching profession, London: Routledge.

Troman Geoff and Woods Peter. (2001), Primary teachers'stress, London, Routledge Falmer, UK. 
Tytherleigh. M.Y and Cooper. (2007), "Gender, Health and Stress in English University Staff: Exposure or Vulnerability", Applied Psychology: An International Review, Vol. 56 No.2, pp. 267-287.

Winefield Anthony H, Gillespie Nicole, Stough Con, Dua Jagdish, Hapuarachchi John and Boyd Carolyn. (2003), "Occupational Stress in Australian University Staff: Results from a National Survey", International Journal of Stress Management, Vol. 10, No. 1, pp. 51-63

Yin, R. K. (2009), Case study research: Design and methods, Newbury Park, CA. Sage. 